Article

\title{
Groundwater Governance: The Role of Legal Frameworks at the Local and National Level-Established Practice and Emerging Trends
}

\author{
Kerstin Mechlem \\ International Natural Resources Law and Human Rights Consultant, 69120 Heidelberg, Germany; \\ k.mechlem@gmail.com; Tel.: +49-6221-4208-179
}

Academic Editors: Sharon B. Megdal, Susanna Eden and Eylon Shamir Received: 4 May 2016; Accepted: 10 August 2016; Published: 17 August 2016

\begin{abstract}
Legal frameworks play a crucial role for effective groundwater governance. They flank and support water policy and provide users and the administration with rights and obligations to use, manage, and protect vital resources in order to achieve the overall goal of equitable and sustainable water use. This paper discusses key challenges that have to be addressed in water law to manage and protect groundwater effectively. It will provide an overview of established practice in groundwater legislation and discuss recent trends and developments in light of current challenges. It focuses on permit-based systems of administrative water rights but will to a limited extent also deal with customary, community-based, and informal arrangements. It will show that increasingly domestic groundwater legislation is strengthened and ranked on a par with surface water regimes, ideally by dealing with all water resources in an integrated manner.
\end{abstract}

Keywords: water law; groundwater law; legislation; governance; water management; institutions; human rights; abstraction control; pollution control; environmental law

\section{Introduction}

"[T]he existence, origin, movement and course of [underground] waters, and the causes which govern and direct their movements, are so secret, occult and concealed, that an attempt to administer any set of legal rules in respect to them would be involved in hopeless uncertainty, and would be, therefore, practically impossible."

Although groundwater has traditionally received less attention than surface water in policy and law, views as expressed in this quote from Frazier v. Brown (1861), which were not uncommon in the 19th century, are by now fortunately obsolete. Nonetheless, a certain lack of attention to groundwater still manifests itself in piecemeal legislative approaches, inadequate institutional set-ups and insufficient implementation of groundwater law in many parts of the world. Increasingly, however, it is acknowledged that legal frameworks play a crucial role for effective groundwater governance, which need to flank and complement science and policy. Modern water laws take an integrative approach to surface water and groundwater resources, define clear rights and obligations, set up management tools, protect quantity and quality, involve stakeholders and are matched with robust institutions in charge of their implementation. They regulate, amongst other issues, the conditions for access to groundwater, the protection of aquifers against depletion and pollution, the use of monitoring and planning tools, the way private and public interests have to be balanced and the involvement of stakeholders in decision-making and management processes. Typically, formal legislation addresses these issues. In some parts of the world, however, informal and customary rules continue to play a significant role that has to be acknowledged. 
This paper will provide an overview of established practices as well as recent trends in groundwater legislation. It will discuss key challenges that legislation has to address to manage and protect groundwater and to effectively counter the unsettling effects of groundwater depletion and pollution. The latter are on the rise globally due to groundwater overexploitation and are likely to increase in times of climate change. The article focuses on a comparative analysis of domestic legislation. The examples provided from legislation worldwide are exemplary and, due to the breadth of the subject matter, in no way comprehensive. Where one of the more than 592 transboundary aquifers (including transboundary groundwater bodies as defined in the EU Water Framework Directive) is at stake, the domestic legal frameworks have to take account of and reflect international water law obligations and obligations from other areas of international law, such as human rights laws [2,3]. These will be addressed to the extent necessary without going into the details that have been discussed elsewhere [4-7].

Modern technologies allow using the subsurface for a range of newer activities, which may contaminate groundwater. Among them are the storage of hazardous waste such as nuclear waste, nuclear testing, the injection of fluids for soluble mineral extraction, the storage and recovery of heat and hydrocarbons, carbon capture and sequestration (CCS), hydraulic fracturing ('fracking'), and the injection of residual geothermal fluids. These activities pose new challenges, and to a large extent require specialized laws and regulations which overall still need to catch up with technological developments. Their regulation is beyond the scope of this paper, while their impacts on groundwater make groundwater protection rules, particularly with respect to groundwater quality, ever more relevant.

\section{Recognizing the Importance of Human Rights}

Until a few years ago water laws made no mention of the human right to water. Indeed, the right to water itself - an implicit element of the right to an adequate standard of living recognized most prominently in the 1966 International Covenant on Economic, Social and Cultural Rights-received very little attention [8]. This situation changed when the United Nations Committee on Economic, Social and Cultural Rights General adopted General Comment No. 15 in 2002 [9]. The latter marked the beginning of a quickly developing debate on the right to water, which resulted, inter alia, in the recognition of the right to water in United Nations General Assembly and Human Rights Council resolutions, numerous constitutions and an increasing number of water laws [10].

The right to water entitles everyone to sufficient, safe, acceptable, physically accessible and affordable water for personal and domestic uses [9]. The right to water poses an obligation upon the state to ensure such access in a non-discriminatory manner. It has implications for water resources legislation and for the regulation of the water industry.

In water resources legislation drinking and domestic uses have to take priority over other uses. Whereas such priority has traditionally been accorded to drinking water needs in the allocation of water to different uses, framing a water law in human rights terms adds a new dimension by elevating drinking water needs to requirements as of right instead of policy choice, i.e., to entitlements. Due to the generally superior quality of groundwater compared to surface water groundwater is often ideally suited to the satisfaction of the right to water. Human rights considerations also play a role in the protection of water resources from contamination, the regulation of abstraction to prevent dropping water tables and drying up of wells and many other issues. With respect to the regulation of the water industry, these include appropriate pricing policies, freedom from arbitrary or unjustified disconnections from the supply network, and non-discriminatory access to sufficient and continuous water supply. In many countries, the quantities and uses of water protected by the right to water fall into the category of permit-free de minimis uses (see below, No. 5.), the protection of which therefore may not be compromised unless access to a different source of water is guaranteed. The human right to water requires a look at all water laws, policies, and strategies through a human rights lens and to measure them against human rights criteria, particularly with respect to non-discrimination. 


\section{Groundwater as a Public Good}

As much as access to water is deemed a human right, water as a resource is by now overwhelmingly regarded as a public good.

Historically, the opposite was the case for groundwater. Being a "hidden resource" it was often treated as a private good accessible to owners of land and out of the purview of public regulation. Water rights were essentially a subsidiary component of land tenure rights, i.e., the right to use groundwater was conferred on the owner of the overlying land. In many non-western systems, groundwater could not be privately owned. In Islamic law groundwater is considered a public good, but the ownership of a well entails ownership of a certain amount of adjacent land called harim or forbidden area. It varies in size according to different schools [11]. Customary regimes in many parts of the world view groundwater resources as belonging to the community and reject the concept of individual rights over water.

Better understanding of the characteristics and nature of groundwater and increasing pressure on the resource have instilled a predominant trend to vest ownership and control over all water resources in the state or to recognize the state's superior right to the management of water resources [12]. The state becomes the guardian or trustee of groundwater resources. The right to access and use of groundwater is independent of the regime of the overlying land. Any user who wants to abstract groundwater must apply for a permit (also styled license, authorization, or concession) in order to obtain a "right to use". The separation between ownership and usufructuary rights is one of the cornerstones of modern formal water rights regimes and allows the government to manage and protect groundwater resources in the interest of the public.

In some parts of the world, rules granting private ownership of groundwater persevere. For instance, in Texas, India, or Pakistan the rule of capture is still dominant, allowing landowners to extract groundwater freely on their land [13]. As a result, regulation of access to and extraction of groundwater in the interest of the public is very weak in those countries.

More importantly, even where groundwater is formally a public good and users have only usufructuary rights, perceptions of it being "private" often linger on. They interfere with compliance with government regulation or generate transition problems from an unregulated to a regulated regime. The legal notion or the perception of groundwater being private property can be a strong driver for overexploitation. Socially more equitable access to groundwater and sustainable management depends thus on severing the link between land ownership and control over groundwater and on supporting such change by educational and awareness raising measures.

Customary laws have their own approaches to ownership issues. Customary regimes in many parts of the world regard groundwater resources as belonging to the community and reject the concept of individual rights over water. In much of Africa and Asia, customary water rights are intrinsically linked to land and embedded in land tenure [14]. Formal water legislation might provide for the recognition of customary water rights, which is an emerging trend reflected in recent water legislation from countries as diverse as Bhutan, Namibia, Peru, Tanzania, and Zambia $[15,16]$. States resort to a variety of approaches [17]. Mozambique (Water Licensing Regulations, 2007), for instance, grants priority of allocation to customary water rights. The same applies to the customary rights of traditional communities in Paraguay (Law on Water Resources, 2007). Another option is to order or allow the transformation of a customary right into a statutory right (Water Law of Tucuman Province, Argentina, 2001; Tanzania's Water Resources Management Act, 2009). Others, e.g., Namibia (Water Management Act, 2013), place the government under a duty to have regard to customary rights and practices when considering applications for a borehole license or a license to abstract water). Unfortunately, a large number of water laws protect customary water rights but do not provide the necessary details on the interface between customary and statutory rights, thereby creating legal uncertainty as to their de facto status and protection [17]. 


\section{Groundwater Exploration}

Borehole digging or drilling and well construction for exploration and exploitation are the first steps towards groundwater use. To protect groundwater, to retain control of and information over access to it, and to prevent conflict among users, groundwater exploration and borehole digging or drilling tend to be subject to prior notification, a permit, or registration, as legislation from countries as diverse as Kenya, Kyrgyzstan, Namibia, the Northern Territory of Australia, Oman, the Philippines, or Costa Rica (with a piece of special purpose legislation) [18] demonstrates. In addition, there are rules on borehole construction, well maintenance, and the sealing of abandoned wells. Obligations to sample and to file drilling reports ensure that drillers supply groundwater data to the administration [19]. Legislation may impose drilling fees may and the maintenance of boreholes registers.

In view of the skills required, legislation may subject the exercise of the profession of commercial well digging or drilling to registration or licensing requirements to ensure that the driller is appropriately qualified and that borehole construction standards are maintained [20]. Where this is the case, registries of drillers are often kept. In many cases, however, the drilling industry is not regulated and opportunities for getting away with poor constructions standards abound.

\section{Groundwater Quantity Protection: Regulating Abstraction and Recharge}

Where water demand outstrips supply, significant negative environmental impacts are likely to occur. These can be felt on groundwater through (1) diminishing water tables and eventual depletion of an aquifer; (2) migration of low quality water; or (3) salinization in coastal areas. Equally it can impact negatively on springs, seepage zones, and the baseflow of rivers. Often, social and economic repercussions ensue. Since 2011 the ongoing drought in California, for instance, has caused tremendous aquifer overdraft resulting in significantly declining groundwater levels (often below historic lows), land-subsidence in part of the Central Valley, and a rush for digging ever deeper wells [21].

Water rights are the central element of most current water laws to control water demand. Under a system of water rights, users have to acquire a permit before (ground-)water can legally be abstracted. This obligation is incumbent upon whoever the user is, including state agencies such as those involved in the development of irrigation schemes. Small-scale or de minimis uses are usually exempt (see below). Permit-based systems have gained prominence, in particular since more powerful pumps, population growth, and economic development have driven demand for groundwater, often in excess of supply. They enable the water administration to allocate water to different uses ranging from domestic, agricultural, and industrial uses to environmental ones such as sustaining wetlands and the baseflow of rivers.

Although permit-based systems have long been in place, in many countries, including western ones, the regulation of groundwater still lags behind the regulation of surface water. An example is the Canadian province of British Columbia where as late as 29 February 2016, with the entry into force of the new Water Sustainability Act, nondomestic groundwater use was licensed and made subject to fees and rentals [22]. Prior to this change even large industrial users like the bottling company Nestlé Waters Canada that bottles 265 million liters per annum could take limitless amounts of groundwater for free even in situations of drought [23]. Under new regulations (Water Sustainability Act) fees will be charged, which are, however, heavily criticized as being too low for industrial users and which might undergo further revision [24].

Permits are typically granted for a renewable time period, which is short enough to provide the state flexibility in the resource management, on the one hand, and provide a stable basis for the user for planning and investment decisions, on the other hand. The length of this time period varies considerably ranging from very short (e.g., 5 years) to very long (e.g., 50 years) and depends on local context, the purpose of abstraction, and the state of the aquifer.

Permits provide for annual or seasonal volumetric allocations or are based on an area quota. They also state the abstraction purpose, water protection measures, and the amount of fees or charges due, among other things. Permits require that use be made of the water right failing which the right 
will lapse ("use-it-or-lose-it" rule). An exception is Chile which imposes a tax in case of nonuse [25]. The metering of wells is often imposed in order to verify compliance with the conditions attached to a permit and to measure the amount of water abstracted. Permit holders have the obligation to report regularly (normally on an annual basis) how much water has been abstracted. Where the transaction costs of metering would be too high, estimates are sometimes used. Permits are usually recorded in a registry, which serves as a tool for planning purposes as much as a record and legal evidence of abstraction rights against the claims of third parties and as a source of information to government and fellow or prospective water users.

In some instances, legislation determines the overall amount of permitted withdrawals per year. One example is the Edwards Aquifer Authority Act (Texas), which precludes the Edwards Aquifer Authority from authorizing withdrawals from the entire aquifer exceeding 572,000 acre-feet (approximately 705,550 cubic meters) of water annually [26]. Another example is the Namibian Water Resources Management Act (2013), which empowers the Namibian Water Minister to restrict or limit groundwater abstraction to ensure that the total abstraction of the water permitted from an aquifer does not exceed the volume of water, which can be abstracted over a period without adversely affecting the quantity and quality of the water or the environment above [27]. In the same direction goes Tanzania's Water Resources Management Act (2009).

In some countries, e.g., Australia, Chile, and the US, users can trade groundwater abstraction permits, subject to some form of prior involvement of the water administration to protect both private and public interests and to mitigate negative impacts of such trades [28]. Other countries, especially in South Asia, have informal water trading schemes. Worldwide there is no clear trend on the sensitive issue of trading water permits, with recent water legislation in as many cases allowing as prohibiting it $[15,29]$.

Administrating and implementing a permit system is a costly, administratively challenging, and time-consuming process, especially in countries with very high numbers of small-scale users. The introduction of a permit system is likely to fail where it is not well designed and tailored to the local context and administrative capacity.

For administrative and user convenience and cost it is standard practice to exclude small-scale or de minimis uses-which are particularly important in developing countries-from permit requirements. Such de minimis uses can be defined with regard to volumes, area, or purpose and need to take into account local conditions. Widely accepted de minimis uses include the use of water for drinking, watering domestic animals and poultry, recreational uses such as bathing, meeting of basic household needs, the watering of garden plots, and firefighting [30]. Defining de minimis uses is a tricky task that requires taking into account local circumstances. While for instance in the Murray-Darling basin small-scale users are allowed to extract water without a permit for domestic or livestock needs or for irrigating small plots of 2 ha or less, the same rule would exempt over $95 \%$ of current groundwater irrigators if applied in South Asia or on the North China plains [31].

In terms of water tenure, users face the disadvantage that even where de minimis use is described in terms of a right to abstract water and use it for specific purposes, it may be difficult to assert an unquantified right against the state or other users in case of drying up wells or polluted water. Insofar individual de minimis rights lack security and often also equitable mechanisms for allocation, even where legislation protects de minimis uses as a category [30,32].

The protection of the significant social and public health benefits derived from small-scale uses requires effective aquifer planning and protection measures to prevent de minimis sources from running dry or becoming unfit for use. A permit can be made a prerequisite for drilling so information about the location of wells for de minimis uses is available. Cumulatively, or alternatively, a reporting regime whereby users are required to periodically provide details of their abstraction and use of groundwater can help to keep the scope of de minimis uses under review. Community management approaches may provide further options for groundwater allocation and protection for de minimis uses.

The protection of groundwater from overdraft requires regulation not only of abstraction but protection, and in some cases artificial enhancement, of recharge. 
Natural groundwater recharge processes have to be protected from land-based interference including paving, development, or logging. Land surface zoning is a tool often applied to protect recharge areas and to establish zones where abstraction is restricted or prohibited. Also, other land management measures such as changing cropping or irrigation practices offer scope to regulate recharge to improve groundwater quantity. Under certain conditions, recharge rates under cropland may increase by one to two orders of magnitude compared with native perennial vegetation [33]. Equally, reducing or changing highly water-intensive cropping practices preserve precious groundwater resources. An example is the Indian States of Punjab and Haryana, which prohibited to sow paddy nursery and to transplant paddy before certain dates in May and June to avoid the high evaporation rates in early summer [34,35]. Robust effects on reducing groundwater depletion have been reported for the Punjab [36].

Recharge can be enhanced through traditional water conservation measures and artificial direct surface or subsurface as well as indirect recharge techniques. Managed aquifer recharge is the intentional recharge and storage of water (river water, reclaimed water, desalinated seawater, rainwater, or groundwater from other aquifers) into an aquifer for subsequent recovery or for environmental benefits using spreading and infiltration techniques or injection wells. It is used for a number of purposes, including replenishing an aquifer to increase the water table and storing water for drought and emergency supplies. Managed aquifer recharge schemes require prior authorization. Licenses are required for the abstraction of the source water, storing of water, aquifer recharging, and re-abstracting water [37]. Legislation also requires that certain conditions are met as to the qualifications of the operators in the sector and to water quality.

Some legal instruments, such as the 2011 Indian Draft Groundwater Model Bill, explicitly call for a number of measures to protect and enhance recharge, namely water harvesting, including rooftop rainwater harvesting, catchment conservation using appropriate groundwater structures or pits, the creation of protection zones in natural recharge areas and in areas that require special attention with regard to the artificial recharge of groundwater, programs for the recharge of aquifers, setting up artificial recharge structures, afforestation, and reforestation [38]. The Andhra Pradesh (India) Land, Water and Trees Act and Rules (2002) explicitly enables the relevant authority to issue guidelines for constructing appropriate rainwater-harvesting structures in all residential, commercial, and other premises and larger open spaces [39].

\section{Groundwater Quality Protection: Pollution Control}

Groundwater quality protection-with a view to protecting public health and achieving social, economic, and increasingly environmental objectives such as minimizing harm to dependent ecosystems-is the second main goal of legal frameworks for groundwater. A plethora of activities and a much wider set of actors than groundwater abstractors causes groundwater pollution and degradation, which are under certain conditions irreversible. Causes of pollution are inappropriate drilling, abstraction, and well maintenance practices resulting in contamination from the well, inter-aquifer leakages or saline water intrusion, pollution caused by polluted surface (river, lake) water, and, in particular, pollution caused by land-based activities.

Groundwater quantity and quality protection are interrelated. Poorly performed drilling operations, inadequate well construction and maintenance, and poor well-casing may result in contamination from the well or inter-aquifer leakage and groundwater degradation by mixing water from different aquifers/layers of aquifers of different quality. Drilling and pumping can mobilize naturally occurring pollutants such as arsenic or fluoride or induce saline intrusion or the migration of lower quality or brackish waters. In many small island states such as The Bahamas and Barbados or Malta, salinization from overpumping of aquifers and thus salinity intrusion into the islands' underlying freshwater lens is a matter of great concern [40,41]. The regulation of the profession of drillers, groundwater exploration, and groundwater abstraction (discussed above) serve groundwater 
quality protection purposes, as do regulations on borehole construction, well maintenance, and the sealing of abandoned wells.

Land-based activities causing pollution fall broadly into two categories, each triggering distinct legal answers. Point-sources of pollution relate to pollution whose entry point into an aquifer can be established with sufficient certainty such as landfills, waste dumps, industrial accidents, mines, and the underground storage of substances. In contrast, non-point source pollution originates from diffuse or indistinct sources, often spread over relatively large areas, whose origins, entry point into groundwater, and impact are difficult or impossible to determine with accuracy. The prime example is agricultural runoff, but stormwater runoff in urban areas and airborne pollution transmitted by precipitation also play a role.

Point-source pollution is addressed by absolute prohibitions or limitations on emitting certain substances. Polluting activities may be made conditional upon a wastewater or pollution discharge permit, prior treatment of the substance, and compliance with effluent standards [11]. The regulation of potential causes of point-source pollution includes provisions aimed at preventing harm to groundwater resources, such as regulations on mining activities or the sitting and operation of landfills or storage tanks and the use of best available technologies. Non-point source pollution prevention measures include the regulation of land uses giving rise to diffuse discharge and the imposition of best agricultural and environmental practices. They include prohibiting or limiting certain polluting and water-using activities; limiting the use pesticides, herbicides, and fertilizers, especially to reduce nitrogen and phosphorus built up; restricting certain cropping patterns; reducing animal-grazing intensity; land reclamation; and drainage [19]. The whole array of actors involved in land use and pollution management-including urban water supply utility managers and agricultural and environmental agencies seeking to regulate the application of fertilizers (e.g., nitrates) and pesticides-have to be involved in groundwater quality protection and addressed by legislation. Given growing pressures on aquifers it becomes increasingly acute to develop and coordinate land use plans, in both urban and rural areas, with river basin or aquifer development plans.

Water quality standards and threshold values are a related mechanism to protect groundwater quality. For the members of the European Union (and for accession countries) the EU Water Framework Directive and its daughter directive on the Protection of Groundwater against Pollution and Deterioration provide a particularly stringent system of groundwater quality protection [3,42].

Land surface zoning is used for critical areas of high vulnerability, including recharge areas, to restrict or prohibit activities with adverse impact on groundwater, such as industrial chemical handling or effluent discharge to the ground, mining, or certain agricultural land use practices. The protection of drinking water sources is a particularly important case in point: the capture zones of the main areas of potable water-supply abstraction require to be designated as protected areas. Successful zoning depends on sufficient knowledge about the characteristics of the aquifer, on land use planning processes, which take groundwater issues appropriately into account, and on a set of accompanying measures that support the restrictions brought about by zoning.

\section{Responding to Environmental Concerns and Climate Change}

As groundwater resources are becoming overly used and polluted, environmental concerns play a more and more prominent role in groundwater legislation. The principle of sustainability has emerged as a key crosscutting principle and cornerstone of modern groundwater legislation. Equally, other principles of environmental law such as the precautionary principle and the preventive principle increasingly feature in water law. European Union directives and-for transboundary groundwater resources-European international legal instruments such as the 1992 European Convention on International Rivers and Lakes and its accompanying 2012 Model Provisions on Transboundary Groundwaters [43,44] most clearly bear out this tendency, but it can equally be observed in legislation from other regions of the world such as from Bhutan (Water Act) [45], Uruguay (National Water Policy Law) and Venezuela (Water Law) [46,47]. The obligation to use and manage aquifers 
sustainably preserves the integrity of aquifers and protects the demands of the environment and of water-dependent ecosystems such as wetlands in the discharge areas of aquifers as much as human needs.

The principle of sustainability is expressed in a variety of ways [48]. It plays a role in allocation decisions and planning processes where the recharge capacity of an aquifer has to be taken into account. Environmental objectives support the allocation of groundwater to groundwater-dependent ecosystems and the baseflow of rivers. The viability of aquatic ecosystem and protected area sustenance may take precedence over other demands competing for water at times of scarcity except those protected by the right to water. Abstraction and pollution discharge permits must meet environmental criteria, and if environmental concerns so require then abstraction rights may be curtailed or revoked, which may raise intricate issues of compensation. Where transfers of an abstraction right are permitted, the environment may not be harmed. Environmental concerns can be taken into account in determining the charges for water abstraction and wastewater disposal and they play a significant role in zoning and planning $[15,29]$. For instance, zones may be established in recharge areas to protect the aquifer as well as in discharge areas to protect wetlands.

The obligation to carry out environmental impact assessments is becoming a prerequisite for the granting of abstraction or discharge permits above a certain quantity of water or before allowing projects of industrial, agricultural or other type with potentially negative impact on aquifers. The water legislation of a large number of countries-among them jurisdictions as diverse as Cameroon, Mexico, Kenya and Paraguay [48] — gives evidence of this trend.

The allocation of water to an "environmental reserve" as in Namibia, South Africa, Tanzania, or Zambia aims at promoting sustainable use of water resources and preserving dependent ecosystems such as wetlands [49-52].

An environmental concern of particular salience is climate change, one of the big challenges of the future with pervasive impacts on the water sector, including on groundwater availability and quality. The interactions between groundwater and climate change are diverse, depending on the context, and still largely uncertain. It is, however, certain that there will be direct and indirect impacts.

Among the direct impacts are changes in precipitation and evapotranspiration, which may reduce groundwater recharge and result in falling water tables. Climate change is projected to reduce renewable surface and groundwater resources in most dry subtropical regions [53]. Increases in the frequency and severity of floods may result in higher surface runoff and soil erosion, possibly also reducing recharge. Preliminary evidence suggests that changes in snowmelt regimes will reduce the seasonal duration and magnitude of recharge [33]. In other regions recharge may increase and groundwater levels rise. Sea level rise and storm surges will put coastal and island aquifers at risk of saline intrusion [33].

Indirect effects of climate change on groundwater occur through increases in demand on groundwater in a warming climate, in particular irrigation demand, and changes in the availability of different water sources. In adaption to increases in precipitation variability, the importance of groundwater is likely to increase.

It is necessary to assess continually the impact of climate change on water resources and, where necessary, to take measures, such as the possibility to revoke abstraction permits, as a consequence of climate-induced deterioration of the state of an aquifer. With few exceptions climate change is not yet a specific concern in modern water policy and law. While scarcity and sustainability are addressed, the broader connections between climate, water, forests, and land use are often not yet tackled in mitigation attempts. Where environmental legislation addresses climate change it often remains at a generic level. Especially land use and its effects on groundwater have to be addressed as interlinked issues.

National action plans on climate change tend to address inadequately impacts on water resources, and action plans on climate change and water are not sufficiently interlinked. Positive examples of the contrary are the 2012 Murray Darling Basin Plan (Australia), which is based on the 2007 Water 
Act (a Commonwealth statute amended in 2008) and deals with the nexus between water resources, including groundwater, and climate change (see Sections 4.03, 5.03, 6.06, 8.04, 8.07, 10.51) [54]. Also, the Draft National Water Framework Bill of India (2013) refers to climate change in its sections on project planning and management, and on coordination and policy support mechanisms [55]. In contrast, Indian state-level groundwater laws, the Indian 2005 Model Bill to Regulate and Control the Development and Management of Groundwater and its planned successor, the 2011 Draft Model Bill for the Conservation, Protection and Regulation of Groundwater, only refer to environmental protection but do not address climate change directly $[38,56]$.

\section{Monitoring}

The main piece of water legislation tends to contain obligations to monitor groundwater use and status, while subsidiary legislation or technical guidelines sets out detailed parameters. Groundwater quantity and quality monitoring provide the basis for planning, allocation, and conservation decisions. Legislation may (and should) require groundwater-related institutions to coordinate data-gathering, interpretation, and storing.

Information from modeling and monitoring enables scientifically-based management decisions to ensure that in case of aquifers under pressure water remains available and of sufficient quality. Water rights remain secure and are not threatened by falling water tables putting water out of reach or deteriorating quality attributes making water unfit for the purposes a right was granted for. Once baseline data of the characteristics of an aquifer system is available, regular monitoring of changes in flow, storage, and water quality informs about the impact of abstraction and pollution activities. Inventories of wells (sometimes limited to certain locations or to wells showing specific characteristics), registers of abstraction and wastewater discharge permits, the information provided by well owners on their abstraction, and the data made available through monitoring together enable the water administration to recognize critical situations and to intervene accordingly. Monitoring also helps to establish liability, for instance for polluting incidents, although the concealed and inaccessible nature of groundwater and the slow changes in quantity and quality cause difficulties in practice.

Monitoring aquifers is a technically demanding and costly exercise so that information about many aquifers is highly incomplete. The costs for setting up a monitoring network, collecting data regularly, processing, interpreting, and storing it in databases, including unified databases at the national level, are one of the reasons why in developed and developing countries alike water rights and monitoring obligations, especially with respect to groundwater, may remain unimplemented.

\section{Planning}

Water legislation regularly requires resource management plans, for instance, in Morocco, South Africa, Uganda, South Australia, and Texas and by the European Water Framework Directive [32]. Water management plans are developed to promote rational, effective, and fair water management and decision-making. In some countries they may even have a legally binding nature.

They typically contain the characteristics of a river basin or aquifer, a review of the impact of human activity, objectives with respect to quantity and quality of the resource and measures to meet the objectives. In the case of nonrenewable aquifers, or of aquifers for which a policy choice in favor of mining has been made, the plan may need to address depletion. Where the water legislation does not establish development and management priorities, a management plan may include them.

The type of plan the respective legal and institutional framework provides for depends on the hydrogeological setting, the degree of surface-groundwater linkage and the significance of the aquifer. For significant aquifers or fossil aquifers, management plans can be developed to complement integrated water resource planning at the national level. An example is the Groundwater Management Plan for the important Edwards Aquifer in Texas, which guides the activities of the Edwards Aquifer Authority. Other examples are the Draft Model Groundwater Model Bill of India that suggests 
aquifer-based use and protection plans [38] and the water legislation of Algeria, which establishes important aquifers as units for planning [57].

Alternatively, as all recharging aquifers occur within river basin management units, groundwater can be integrated into river basin planning. Where legal and institutional frameworks are weak or do not adequately cover institutional responsibility for groundwater resources or groundwater user groups are not represented in a river basin agency or the agency's personnel lacks groundwater knowledge, such an approach might, however, be premature [58].

There is a clear trend to involve stakeholders in plan preparation and revision. Participation in planning processes under the EU Water Framework Directive is a case in point: under Art. 14 of the EU Water Framework Directive, Member States shall encourage the active involvement of all interested parties in the implementation of the EU Water Framework Directive and in particular in the production, review, and updating of river basin management plans, which are mandatory for all basins under the directive [3].

\section{Designing Effective Multilevel Institutional Set-Ups}

Institutional set-ups to manage aquifers and to administer water rights vary highly across countries. As discussed in depth elsewhere, in most countries a plethora of multilevel water resources administration institutions exists [11]. As intensive development of groundwater is recent, institutional responses tend to lag behind the tasks created by legislation. In federal countries, federal, state and local institutions may be vested with functions and powers in respect of groundwater. Only a few countries have attempted to set up dedicated groundwater management agencies.

The highest and ultimate responsibility for water resources management is often conferred upon one or more ministers, usually acting through a statutory Director or Director-General of water resources, such as the Department of Water and Sanitation in South Africa, or some other statutory body such as an authority (e.g., the Jamaica Water Authority) or agency (e.g., the Environment Agency in England) or Directorate of Waters (e.g., the Direccción General de Aguas in Chile) [30,59]. Ideally, the entire range of groundwater management issues is placed in the hands of a single water resources institution, which would also be in charge of surface water [60]. While such a set-up, which reflects allegiance to the principle of integrated water resources management, is still more exception than rule, recent water legislation of a number of countries, among them Honduras, Peru, Tanzania and Zambia, point to a consolidating trend in this direction [15]. An inter-ministerial/interagency mechanism such as a council, commission or committee usually has the task of coordinating those ministries and agencies that have a stake in aquifer management [19].

The main tasks of a water authority comprise planning and modeling future demands and impacts on water resources, organizing stakeholder fora, monitoring water quality and quantity, issuing and administrating water rights, including the maintenance of registers, and implementing and enforcing the water law and water rights regimes, e.g., by meting out administrative fines in cases of non-respect for legal obligations or the terms and conditions of a permit [59]. Water authorities often fall short of delivery on these tasks due to institutional weaknesses, lack of empowerment and finances, gaps in mandate, and a number of other factors. Institutional deficits inevitably result in implementation deficits, which erode the contribution a legal framework can make to protecting and managing an aquifer.

There is a trend to complement the water resources institution, which bears overall responsibility throughout the jurisdiction with coordinating/decision-making institutions at the drainage basin or aquifer level. The scope of institutions set up at the river basin often includes groundwater management, even where aquifer boundaries do not follow the boundaries of the river basin. E.g., under the Art. 3 Water Framework Directive where groundwater does not follow a particular river basin it is assigned to the nearest or most appropriate river basin [3]. Less frequently, a mechanism is set up specifically at the aquifer level. 
In federal countries, large aquifers spanning several states may call for interstate institutional mechanisms. This is the case of the Great Artesian Basin (GAB) shared by Queensland, New South Wales, South Australia, and the Northern Territory, one of the largest basins in the world covering $22 \%$ of Australia, for which the Australian and state/territory governments in consultation with the GAB Coordinating Committee (community and sector representatives), national organizations, landholders, and water users develop a Strategic Management Plan.

Where the scale of groundwater issues is rather small, local solutions may be the most appropriate given the localized nature of groundwater access and use. In such circumstances local level groundwater management by self-organized user groups may be a promising and appropriate approach.

The legislation of a number of countries provides for the establishment of (ground-)water user associations or aquifer management organizations, for instance Chile, Spain, Mexico, Australia, and the western states of the US [61]. They have been established especially where aquifers are at risk of being degraded or depleted. The Spanish Water Law of 1985 (revised in 2001) makes the establishment of groundwater user organizations compulsory in overexploited aquifers [62]. In a number of western states of the U.S. groundwater management or conservation districts, a form of water users association, have been established in respect to about $89 \%$ of groundwater resources. Local users control them and may set limits on pumping and wells, adopt groundwater management and development policies and programs, and propose water allocations criteria. In Mexico, where groundwater resources are severely overexploited, COTAS (Comités técnicos de aguas subterráneas—technical groundwater committees) have been created. They are civil society organizations, which are supported financially by the public hand. The National Water Commission carefully facilitated their set-up. Inter alia, the COTAS support the implementation of groundwater management plans, support the government in groundwater rights administration, provide services to groundwater users, support consensus-building for future integrated water resources management, establish dialogue with groundwater users, and help improve data (e.g., by helping the water administration to validate, update, and correct databases on wells) [63].

Also, the Expert Group on Ground Water Management and Ownership of the Indian National Planning Commission suggested a shift in focus from state control to community management by user groups because of difficulties of implementing a permit-based system. It recommended that user groups be responsible for planning the use of groundwater within groundwater management units. Based on the goal of sustainable-yield management, withdrawal should not exceed long-term recharge. The Central Ground Water Board and the State Ground Water Board would be responsible for scientific monitoring of groundwater levels and for estimating a sustainable level of groundwater use. In case water levels fell below the replenishable level, the Central government could declare an area as "environmentally threatened" and, in consultation with stakeholders, a strategy for addressing this problem would be developed [64].

Stakeholder self-organization depends on a number of conditions. It can occur where strong community values and norms exist, particularly if they are embedded in and facilitated by a conducive larger regime [65]. A well-informed community of groundwater users may agree on maximum acceptable drawdowns in pumped wells or ban the application of pesticides across an aquifer that furnishes potable water supplies [66]. Local self-management will need technical support when problems occur, and preferably before, for realistic appreciations of the state of the resource. Management of groundwater resources by user groups also does not replace state regulation, implementation and enforcement, and economic mechanisms, rather the three work as a tripod on which to base aquifer governance [67]. There are relatively few examples of self-organization in relation to the scale and intensity of groundwater development [68].

The legal framework has to define clearly the role and responsibilities of groundwater user groups on the one hand and the water administration and other public institutions on the other. For large-scale groundwater users, such as Coca-Cola in the case of India, a permit and registration approach with clear indications of conditions should exist in parallel to community approaches [69]. Among possible organizational forms are water users associations, groundwater user groups, village water supply 
groups, aquifer management organizations (AMORs), or Non-governmental organizations (NGOs). AMORs have been suggested for larger high-yielding aquifers and should include all local water user associations, groundwater user groups, village water-supply councils etc., and also representatives of national and/or local groundwater resource agencies and of the corresponding local government [70]. The governance arrangements that may work across a small aquifer may not work in large aquifers supplying water to a range of different activities in larger urban, agricultural, industrial, and mining areas [66].

\section{Conclusions}

Modern water legislation based on administrative water rights and a range of planning and monitoring tools has been introduced worldwide over the last decades. It offers mechanisms to strike a balance between growing demand and the need to protect and preserve groundwater resources for current and future generations.

A number of trends in groundwater legislation can be distilled. The human right to water is increasingly recognized not only at the constitutional level but also in water resources legislation. There is a strong trend to treat groundwater as a public and no longer as private good attached to land rights. Administrative permit-based water rights systems are becoming a norm. They tend to work best in highly formalized water economies and always have to take into account local conditions, the existence of customary rules—where applicable—and existing administrative capacity. In developing countries with limited administrative capacity and high numbers of small-scale users they face implementation challenges. Environmental concerns and principles continue to gain importance in (ground-)water legislation. The array of mechanisms apt to deal with the uncertainties generated by climate variability are becoming ever more important as the latter exacerbates the need to strike a balance between the unpredictability of water resources availability and quality, the security of water rights tenure sought by investors and environmental allocations. Stakeholder involvement plays an increasing role in planning and decision-making processes, and management approaches at the community or aquifer level are developing.

All in all, more and more countries strengthen domestic groundwater legislation and rank it on a par with surface water regimes, often by dealing with all water resources in an integrated manner based on the principle of integrated water resources management. These encouraging developments with respect to law, institutions, and administration have to be supported and embedded in supportive policies in other sectors, such as agriculture and energy, to achieve effective and sustainable improvements of groundwater governance and reverse the global trend of groundwater depletion and degradation. Legal frameworks for groundwater have to form an integral part of context-based groundwater governance, which must be adapted to each country's financial, technological and institutional capabilities and be appropriate to its geography and environment, customs, cultures, political systems, and prevailing practices [71].

Acknowledgments: This paper builds on a thematic paper on legal and institutional frameworks prepared for a GEF project on Groundwater Governance. The author was the lead consultant for the legal and institutional work carried out with respect to this output under the project [72].

Conflicts of Interest: The author declares no conflict of interest.

\section{References}

1. Frazier v. Brown; 12 Ohio St. 294 (1861).

2. IGRAC. Transboundary Aquifers of the World, 2015. Available online: http://www.un-igrac.org/sites/ default/files/resources/files/TBAmap_2015.pdf (accessed on 7 April 2016).

3. Directive 2000/60/EC of the European Parliament and of the Council of 23 October 2000 Establishing a Framework for Community Action in the Field of Water Policy. Available online: http:/ / eur-lex.europa. eu/legal-content/en/TXT/?uri=CELEX:32000L0060 (accessed on 15 August 2016). 
4. Eckstein, G. Managing Buried Treasure across Frontiers: The International Law of Transboundary Aquifers. Water Int. 2011, 36, 573-583. [CrossRef]

5. McCaffrey, S. The International Law Commission Adopts Draft Articles on Transboundary Aquifers. Am. J. Int. Law 2009, 103, 272-293. [CrossRef]

6. McIntyre, O. International Water Resources Law and the International Law Commission Draft Articles on Transboundary Aquifers: A Missed Opportunity for Cross-fertilisation? Am. J. Int. Law 2011, 105, 237-254.

7. Mechlem, K. Past, Present and Future of International Law of Transboundary Aquifers. Int. Community Law Rev. 2011, 13, 209-222. [CrossRef]

8. International Covenant on Economic, Social and Cultural Rights. Available online: http://www.refworld. org/docid/3ae6b36c0.html (accessed on 15 August 2016).

9. General Comment No. 15. The Right to Water. Available online: http://www2.ohchr.org/english/issues/ water/docs/CESCR_GC_15.pdf (accessed on 15 August 2016).

10. UN General Assembly. Resolution 64/292 of 28 July 2010. UN Doc. A/RES/64/292 of 3 August 2010. For References to Further Resolutions, Information on the Right to Water in Constitutions and Domestic Legislation See. Available online: http://www.righttowater.info/progress-so-far/ (accessed on 12 April 2016).

11. Caponera, D. Principles of Water Law and Administration, National and International, 2nd ed.; Nanni, M., Ed.; Taylor \& Francis: London, UK, 2007; p. 11.

12. Burchi, S.; Nanni, M. How Groundwater Ownership and Rights Influence Groundwater Intensive Use Management. In Intensive Use of Groundwater: Challenges and Opportunities; Llamas, R., Custodio, E., Eds.; Balkema: Lisse, The Netherlands, 2003; pp. 227-240.

13. Edwards Aquifer Authority V. Day. Supreme Court of Texas. Available online: http://caselaw.findlaw.com/ tx-supreme-court/1595644.html (accessed on 10 August 2016).

14. Meinzen-Dick, R.; Nkonya, L. Understanding Legal Pluralism in Water and Land Rights: Lessons from Africa and Asia. In Community-Based Water Law and Water Resource Management Reform in Developing Countries; van Koppen, B., Giordano, M., Butterworth, J., Eds.; Cabi: Wallingford, UK, 2007; pp. 12-27.

15. Burchi, S. 2009-2011 Year-End Review. Water Law 2011, 22, 248-265.

16. Burchi, S. 2005 Year-End Review. Water Law 2005, 16, 155-179.

17. Burchi, S. A Comparative Review of Contemporary Water Resources Legislation: Trends, Developments and an Agenda for Reform. Water Int. 2012, 37, 613-627. [CrossRef]

18. Reglamento de Perforación del Subsuelo para la Exploración y Aprovechamiento de Aguas Subterráneas. Available online: http://www.da.go.cr/textos/documentos/35884-.pdf (accessed on 10 August 2016).

19. Nanni, M.; Burchi, S.; Mechlem, K.; Stephan, R.M. Sustainable Utilization of Groundwater Resources: Legal and Institutional Aspects. In Non-Renewable Groundwater Resources-A Guidebook on Socially Sustainable Management for Water Policy-Makers; Foster, S., Loucks, D.P., Eds.; United Nations Educational, Scientific and Cultural Organization (UNESCO): Paris, France, 2006; pp. 49-58.

20. Preparing National Regulations for Water Resources Management-Principles and Practice. Available online: http://www.fao.org/docrep/006/y5051e/y5051e00.htm (accessed on 20 April 2016).

21. Assessing CA Groundwater Management One Year after Landmark Legislation. Available online: http:/ / waterinthewest.stanford.edu/resources / forum/assessing-ca-groundwater-management-oneyear-after-landmark-legislation (accessed on 13 April 2016).

22. Water Sustainability Act, British Columbia, Canada. Available online: https://www.leg.bc.ca/Pages/ BCLASS-Legacy.aspx\#\%2Fcontent\%2Flegacy\%2Fweb\%2F40th2nd\%2F3rd_read\%2Fgov18-3.htm (accessed on 7 April 2016).

23. CBC News. Nestlé Faces Renewed Criticism as B.C. Drought Continues. Available online: http://www.cbc. $\mathrm{ca} /$ news/canada/british-columbia/nestlé-faces-renewed-criticism-as-b-c-drought-continues-1.3145929 (accessed on 8 April 2016).

24. Nestlé is about to Suck BC Dry-For \$2.25 per Million Litres to be Exact. Available online: http:/ /action. sumofus.org/a/bc-bottled-water/13/2/?sub=homepage (accessed on 8 April 2016).

25. Ley $\mathrm{N}^{\circ}$ 20.099-Introduce Modificaciones a la Ley $\mathrm{N}^{\circ}$ 20.017, que Modifica el Código de Aguas. Available online: http:/ / faolex.fao.org/cgi-bin/faolex.exe?rec_id=045571\&database=faolex\&search_type= link\&table=result\&lang=eng\&format_name=@ERALL (accessed on 10 August 2016). 
26. Edwards Aquifer Authority Act, 1993. Available online: http://www.edwardsaquifer.org/legislation-andpolicy/the-eaa-act (accessed on 10 August 2016).

27. Promulgation of Water Resources Management Act, 2013. Available online: http://docplayer.net/11376739Government-gazette-of-the-republic-of-namibia-n-36-40-windhoek-19-december-2013-no-5367.html (accessed on 10 August 2016).

28. Solanes, M. Institutional and Legal Issues Relevant to the Implementation of Water Markets. In Groundwater: Legal and Policy Perspectives; Salman, S., Ed.; World Bank Technical Paper No. 456; World Bank: Washingon, DC, USA, 1999; pp. 69-90.

29. Burchi, S. 2008 Year-End Review. Water Law 2008, 19, 223-228.

30. Hodgson, S. Exploring the Concept of Water Tenure. FAO, 2016. Available online: http://www.fao.org/3/ I5435E (accessed on 8 April 2016).

31. Shah, T.; Roy, A.D.; Qureshi, A.S.; Wang, J. Sustaining Asia's Groundwater Boom: An Overview of Issues and Evidence. Nat. Resour. Forum 2003, 27, 130-141. [CrossRef]

32. Van Koppen, B. Dispossession at the Interface of Community-Based Water Law and Permit Systems. In Community-Based Water Law and Water Resource Management Reform in Developing Countries; van Koppen, B., Giordano, M., Butterworth, J., Eds.; Cabi: Wallingford, UK, 2007; pp. 46-64.

33. Taylor, R.G.; Scanlon, B.; Doll, P.; Rodell, M.; van Beek, R.; Wada, Y.; Longuevergne, L.; Leblanc, M.; Famiglietti, J.S.; Edmunds, M.; et al. Ground Water and Climate Change. Nat. Clim. Chang. 2013, 3, 322-329. [CrossRef]

34. The Punjab Preservation of Sub-Soil Water Act, 2009. Punjab Act No. 6 of 2009. Available online: http://agripb.gov.in/abt_deptt/pdf/Pb\%20preservation\%20of\%20Subsoil\%20Act,2009.pdf (accessed on 10 August 2016).

35. The Haryana Preservation of Sub-Soil Water Act, 2009. Available online: http://www.cseindia.org/userfiles / haryana_sub-soil_wateract.pdf (accessed on 10 August 2016).

36. Tripathi, A.; Mishra, A.K.; Verma, G. Impact of Preservation of Subsoil Water Act on Groundwater Depletion: The Case of Punjab, India. Environ. Manag. 2016, 58, 48-59. [CrossRef] [PubMed]

37. Burchi, S. Study on the Legislative Framework Regulating the Recharge of Aquifers with Adequately Treated Wastewater. 2014. Available online: http:/ / www.swim-sm.eu/files/Legislative_framework_regulating the_recharge_of_aquifers_EN.pdf (accessed on 14 April 2016).

38. India, Draft Model Bill for the Conservation, Protection and Regulation of Groundwater 2011, in Planning Commission, Report of the Steering Committee on Water Resources and Sanitation for Twelfth Five Year Plan (Government of India 2012) 154. Available online: http://planningcommission.gov.in/aboutus/committee/ strgrp12/str_sani.pdf (accessed on 16 April 2016).

39. Andhra Pradesh (India). Water, Land and Trees Act and Rules (2002), s. 17. Available online: http:/ / faolex.fao.org/docs/pdf/ind41989.pdf (accessed on 27 July 2016).

40. Intergovernmental Panel on Climate Change (IPCC). Small Island States. Climate Change and Variability. Available online: http://www.grida.no/climate/ipcc_tar/wg2/pdf/wg2TARchap17.pdf (accessed on 14 April 2016).

41. FAO. Malta Water Resources Report. 2006. Available online: ftp://ftp.fao.org/docrep/fao/009/a0994e/ a0994e.pdf (accessed on 14 April 2016).

42. Directive 2006/118/EC of the European Parliament and of the Council of 12 December 2006 on the Protection of Groundwater against Pollution and Deterioration. Available online: http:/ / eur-lex.europa.eu/legalcontent/HR/ALL/?uri=CELEX:32006L0118 (accessed on 15 August 2016).

43. United Nations Treaty Series. 1936 United Nations Treaty Series U.N.T.S. 269; United Nations Treaty Series: New York, NY, USA.

44. Model Provisions on Transboundary Groundwaters. Available online: https://www.unece.org/ fileadmin/DAM/env/water/publications/WAT_model_provisions/ece_mp.wat_40_eng.pdf (accessed on 10 August 2016).

45. The Water Act of Buthan 2011. Art. 43. Available online: http://faolex.fao.org/docs/pdf/bhu106322.pdf (accessed on 10 August 2016).

46. Ley $\mathrm{N}^{\circ} 18.610$ Política Nacional de Aguas. Available online: http://www.ose.com.uy/descargas/ documentos/leyes/ley_18_610.pdf (accessed on 10 August 2016).

47. Ley de Aguas. Available online: http://www.leyesvenezolanas.com/aguas.html (accessed on 10 August 2016). 
48. The Greening of Water Law: Managing Freshwater Resources for People and the Environment. UNEP. Available online: http://www.unep.org/delc/Portals/119/UNEP_Greening_water_law.pdf (accessed on 16 April 2016).

49. Namibia. Water Resources Management Act, No. 11 of 2013. Available online: http://docplayer.net/11376739Government-gazette-of-the-republic-of-namibia-n-36-40-windhoek-19-december-2013-no-5367.html (accessed on 10 August 2016).

50. South Africa. National Water Act, No. 36 of 1998, Part 3. Available online: https://www.dwa.gov.za/ Documents/Legislature/nw_act/NWA.pdf (accessed on 10 August 2016).

51. Tanzania. The Water Resources Management Act, No. 11 of 2009, Art. 33. Available online: http:/ / faolex. fao.org/docs/pdf/tan96340.pdf (accessed on 10 August 2016).

52. Zambia. Water Resources Management Act, No. 21 of 2011. Art. 44. Available online: http://faolex.fao.org/ docs/pdf/zam117433.pdf (accessed on 10 August 2016).

53. IPCC. Climate Change 2014: Synthesis Report. Contribution of Working Groups I, II and III to the Fifth Assessment Report of the Intergovernmental Panel on Climate Change. Available online: https:/ /www.ipcc. ch/pdf/assessment-report/ar5/syr/SYR_AR5_FINAL_full_wcover.pdf (accessed on 20 April 2016).

54. Available online: https://www.legislation.gov.au/Details/F2012L02240 (accessed on 21 April 2016).

55. Available online: http://www.indiaenvironmentportal.org.in/files/file/Draft\%20national\%20framework\% 20bill\%202013.pdf (accessed on 17 April 2016).

56. Available online: http://www.indiawaterportal.org/sites/indiawaterportal.org/files/Model $\% 20 \mathrm{bill} \%$ 20to\%20regulate $\% 20$ and $\% 20$ control\%20development $\% 20$ of $\% 20$ groundwater $\% 20$ by $\% 20$ Ministry $\% 20$ of $\%$ 20Water\%20Resources\%20\%282005\%29_0.pdf (accessed on 20 April 2016).

57. Loi No. 05-12 du 28 Joumada Ethania 1426 correspondant au 4 août 2005 relative à l'eau. Art. 3, 56, 57. Available online: http://www.droit-afrique.com/upload/doc/algerie/Algerie-Loi-2005-12-eau.pdf (accessed on 10 August 2016).

58. Garduño, H.; Foster, S.; Nanni, M.; Kemper, K.; Tuinhof, A.; Koundouri, P. Groundwater Dimensions of National Water Resource and River Basin Planning; GW Mate Briefing Notes Series; World Bank: Washington, DC, USA, 2006.

59. Hodgson, S. Modern Water Rights; Food and Agriculture Organization (FAO): Rome, Italy, 2006.

60. India Groundwater Governance Case Study. Available online: http:/ /www.groundwatergovernance.org/ downloads/GWGovernanceIndia.pdf (accessed on 7 April 2016).

61. Lopez-Gunn, E.; Martinez Cortina, L. Is Self-Regulation a Myth? Case Study on Spanish Groundwater User Associations and the Role of Higher Level Authorities. Hydrogeol. J. 2006, 14, 361-379. [CrossRef]

62. Real Decreto Legislativo $1 / 2001$, de 20 de julio, por el que se aprueba el texto refundido de la Ley de Aguas. Available online: https://www.boe.es/diario_boe/txt.php?id=BOE-A-2001-14276 (accessed on 10 August 2016).

63. Foster, S.; Garduño, H.; Kemper, K. The "COTAS": Progress with Stakeholder Participation in Groundwater Management in Guanajuato, Mexico; GW-Mate Case Profile Collection; World Bank: Washington, DC, USA, 2004.

64. Expert Group on Ground Water Management and Ownership of the National Planning Commission of the Government of India, 2007. Available online: http:/ /www.planningcommission.nic.in/reports/genrep/ rep_grndwat.pdf (accessed on 16 April 2016).

65. Ostrom, E. Reformulation the Commons. Ambiente. \& Sociedade, Ano V No. 10, 1o Semestre de 2002. Available online: http://www.scielo.br/pdf/asoc/n10/16883.pdf (accessed on 16 April 2016).

66. GEF Groundwater Governance Project. Synthesis of Thematic Papers/Case Studies, 2012. Available online: http:/ / www.groundwatergovernance.org/fileadmin/user_upload/groundwatergovernance/docs/ Thematic_papers/GWG_Synthesis_report_update.pdf (accessed on 16 April 2016).

67. Meinzen-Dick, R. Beyond Panaceas in Water Institutions. Proc. Natl. Acad. Sci. USA 2007, 104, 15200-15205. [CrossRef] [PubMed]

68. Moench, M.; Burke, J.; Kulkarni, H. Trends in Local Groundwater Management Institutions \& User Partnerships. GEF Groundwater Governance Project, Thematic Paper No. 7, 2012. Available online: http:/ / www.groundwatergovernance.org/fileadmin/user_upload/groundwatergovernance/docs/ Thematic_papers/GWG_Thematic_Paper_7.pdf (accessed on 16 April 2016). 
69. Nanni, M. Comments on the Report of the Expert Group on Ground Water Management and Ownership of the National Planning Commission of the Government of India. Unpublished.

70. Garduño, H.; van Steenbergen, F.; Foster, S. Stakeholder Participation in Groundwater Management; GW Mate Briefing Note Series; World Bank: Washington, DC, USA, 2010.

71. Groundwater Policy and Governance. GEF Groundwater Governance Project, Thematic Paper No. 5, 2012. Available online: http:/ /www.groundwatergovernance.org/resources/thematic-papers/en/ (accessed on 25 July 2016).

72. Legal and Institional Frameworks. GEF Groundwater Governance Project, Thematic Paper No. 6, 2012. Available online: http:/ /www.groundwatergovernance.org/resources/thematic-papers/en/ (accessed on 7 April 2016).

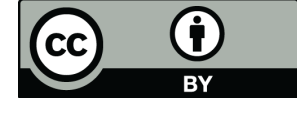

(c) 2016 by the author; licensee MDPI, Basel, Switzerland. This article is an open access article distributed under the terms and conditions of the Creative Commons Attribution (CC-BY) license (http:/ / creativecommons.org/licenses/by/4.0/). 